\title{
Strategi Pemberdayaan Petani Muda Kopi Wirausaha di Kabupaten Simalungun
}

\section{Strategies of Young Farmers Entrepreneurship Empowerment in Simalungun Regency}

\author{
Titik Sumarti ${ }^{1}$, Rokhani², Sriwulan Ferindian Falatehan ${ }^{3}$ \\ ${ }^{13}$ Departemen Sains Komunikasi dan Pengembangan Masyarakat, Fakultas Ekologi Manusia, \\ Institut Pertanian Bogor, Bogor \\ ${ }^{2}$ Fakultas Pertanian, Universitas Jember, Jember
}

\begin{abstract}
Arabica coffee is a product that people all around the world know well. It is also recognized that such a coffee product from Simalungun Regency has high quality to compete internationally. A sustainable coffee business in Simalungun Regency really depends on young farmer entrepreneurs. The young farmers as national asset need more attention from the stakeholders, including the government, to be able to compete in the globalization era. This study used a method of a qualitative approach with primary data. The techniques of data collection were using focus group discussions (FGD). Discussion was held in two times, which each discussion followed by 15 young coffee farmers and also using in-depth interviews with snowballing technique which followed by 11 young coffee farmers. The subjects of the study were young coffee farmers involved in the coffee business. The result shows that it is necessary to emerge two components: driving and facilitating factors as the strategies of empowering young coffee entrepreneurs. The driving factors include the change from the system of non-market economy into the market system, the change from the patron-client system into the market system; opening an access to coffee processing tools, creating the image of young farmers as active and critical agents, and viewing the young coffee farmers as dynamic subjects in building leadership and entrepreneurship characters. The facilitating factors include building collectivity, organizing young coffee farmers by strengthening social capital, protecting water and land resources by applying good agricultural practices (GAP), livelihood diversification, market access, and technology and information-based extension and advisory-based coffee business. In the era of free markets (MEA), it is necessary to reposition the young coffee farmers from producer farmers into suppliers.
\end{abstract}

Keywords: advisory-based, farmer typology, coffee product, entrepreneurs

\begin{abstract}
Abstrak
Kopi arabika merupakan produk global, dan kopi arabika Simalungun mampu bersaing di dunia internasional. Keberlanjutan usaha kopi arabika tergantung pada petani muda wirausaha. Petani muda sebagai aset bangsa perlu mendapat perhatian agar usahanya mampu bersaing di era global. Metode penelitian menggunakan pendekatan kualitatif dengan jenis data primer. Teknik pengumpulan data adalah FGD sebanyak 2 kali masing-masing diikuti 15 orang petani muda kopi dan wawancara mendalam dengan teknik snow ball terhadap 11 orang petani muda kopi. Subyek penelitian adalah petani muda kopi yang terlibat dalam usaha kopi. Hasil penelitian menunjukkan: strategi pemberdayaan petani muda kopi wirausaha memerlukan dua komponen, yaitu faktor penggerak dan pelancar. Faktor penggerak meliputi: perubahan sistem ekonomi non pasar menjadi pasar, perubahan sistem patron klien menjadi pasar; membuka akses alat pengolahan kopi, membentuk citra petani muda sebagai agen yang aktif dan kritis, menempatkan petani muda kopi sebagai subyek yang dinamis dalam membangun karakter kepemimpinan dan kewirausahaan. Faktor pelancar meliputi: membangun kolektifitas, mengorganisir petani muda kopi dengan memperkuat modal sosial, melindungi basis sumberdaya air dan lahan dengan menerapkan good agricultural practices (GAP), diversifikasi mata pencaharian, membuka akses pasar, penyuluhan dan pendampingan usaha kopi berbasis informasi dan teknologi. Dalam era pasar bebas (MEA), diperlukan reposisi petani muda kopi dari petani produsen menjadi petani pemasok.
\end{abstract}

Kata kunci: pendampingan, tipologi petani, produk kopi, wirausaha

\section{Pendahuluan}

Kopi merupakan produk global dan kopi arabika Simalungun mampu bersaing di dunia internasional. Pasar internasional tersebut antara lain Amerika Serikat, Perancis, Jepang, Thailand, Hongkong, Philipina dan Vietnam (Antara, 2012). Keberlanjutan usaha kopi tergantung pada petani

${ }^{1}$ Korespondensi penulis

E-mail: titiksumarti61@gmail.com muda kopi. Petani muda sebagai aset bangsa perlu mendapat perhatian agar usahanya mampu bersaing di era global. Data dari Pusat Data dan Sistem Informasi Pertanian (2013) menunjukkan selama periode 20102012, struktur umur tenaga kerja subsektor perkebunan untuk golongan produktif menengah sebesar 43,12\%, produktif muda sebesar $41,92 \%$, dan produktif tua sebesar 14,96\%. Semakin menuanya tenaga kerja 
pertanian dan subsektor perkebunan di satu sisi, dan di sisi lain lambatnya peningkatan jumlah tenaga kerja golongan produktif menengah serta relatif terbatasnya keterlibatan golongan produktif muda sebagai tenaga kerja memerlukan upaya penanganan serius dari pemerintah.

Sebagai negara dengan produsen kopi keempat terbesar dunia setelah Brazil, Vietnam dan Kolombia, produksi kopi Indonesia sangat tergantung pada usaha perkebunan rakyat. Produksi kopi telah mencapai lebih kurang 650.000 ton per tahun dari sektor perkebunan rakyat $(96,2 \%)$, sisanya dari sektor perkebunan swasta lebih kurang sebesar 10.000 ton $(1,5 \%)$ dan sektor perkebunan negara menyumbang rata-rata 15.000 ton $(2,3 \%)$ per tahun. Provinsi Sumatera Utara merupakan salah satu penghasil kopi arabika di Indonesia. Luas perkebunan kopi rakyat di Sumatera Utara adalah 79.181 Ha, dengan produksi 55.313 ton. (BPS Sumatera Utara, 2013). Salah satu kabupaten yang potensial dalam pengembangan kopi adalah Kabupaten Simalungun (9.966 Ha) (BPS Sumatera Utara, 2013). Keberlanjutan pengembangan kopi arabika di Kabupaten Simalungun ini bergantung pada petani muda kopi. Hal ini sejalan dengan hasil penelitian Ningsih dan Sjaf (2015) dimana pertanian berkelanjutan tidak akan terwujud tanpa adanya keterlibatan pemuda pada kegiatan pertanian, yang meliputi: persiapan lahan dan benih, pemeliharaan, dan panen.

Hasil penelitian Ningsih dan Sjaf (2015) menunjukkan bahwa keterlibatan pemuda pada kegiatan pertanian semakin menurun. Faktor yang membuat rendahnya keterlibatan pemuda pada kegiatan pertanian berkelanjutan adalah sosialisasi orangtua dan kohesivitas teman sebaya yang rendah. Pertanian dianggap sebagai pekerjaan yang tidak menjanjikan secara ekonomi sehingga perlu perhatian berbagai pihak untuk meningkatkan sosialisasi mengenai pertanian serta wadah untuk menfasilitasi pemuda dalam berbagi informasi mengenai pertanian.

Berdasarkan paparan tentang permasalahan ketenagakerjaan di subsektor perkebunan serta keberlanjutan usaha kopi, maka menjadi relevan untuk melakukan penelitian strategi pemberdayaan petani muda kopi wirausaha di Kabupaten Simalungun. Konsep pemberdayaan dalam penelitian ini mengacu pada konsep Ife (1995) dan Suharto (2010) menyatakan bahwa pemberdayaan merupakan sebuah proses dan tujuan. Sebagai proses, pemberdayaan adalah serangkaian kegiatan untuk memperkuat kekuasaan dan keberdayaan kelompok lemah dalam masyarakat, termasuk individu-individu yang mengalami masalah kemiskinan. Sebagai tujuan, pemberdayaan merujuk pada keadaan atau hasil yang dicapai oleh sebuah perubahan sosial yaitu masyarakat yang berdaya, memiliki kekuasaan atau pengetahuan dan kemampuan dalam memahami kebutuhan hidupnya.

Berdasarkan uraian tersebut di atas, pertanyaan dalam penelitian ini adalah: (1) Bagaimana tipologi petani muda kopi di Kabupaten Simalungun? (2) Apa saja faktor penggerak dan pelancar strategi pemberdayaan petani muda kopi wirausaha di Kabupaten Simalungun? (3) Dalam kaitannya dengan pasar global (MEA), apakah persiapan yang perlu dilakukan oleh petani muda kopi? Dengan rumusan pertanyaan tersebut, maka tujuan dari penilitian ini adalah: (1) Menjelaskan tipologi petani muda kopi; (2) Menjelaskan faktor penggerak dan pelancar dalam strategi pemberdayaan petani muda kopi wirausaha; dan (3) persiapan yang perlu dilakukan oleh petani muda kopi dalam kaitannya dengan pasar global (MEA).

Dari rumusan penelitian tersebut, fokus penelitian ini adalah tipologi petani muda kopi, strategi pemberdayaan petani muda kopi dan persiapan petani muda kopi di era MEA. Fokus penelitian ini penting untuk dilakukan untuk membatasi studi kualitatif dan membatasi penelitian guna memilih data yang relevan dengan tujuan penelitian (Moeleong, 2007).

\section{Metode Penelitian}

Metode penelitian menggunakan pendekatan kualitatif dengan jenis data primer. Jenis data primer diperoleh melalui Focus Group Discussion (FGD) dan wawancara mendalam. FGD dilakukan 2 kali masing-masing diikuti 15 petani muda kopi di Nagori Sait Buttu Saribu dan Nagori Pamatang Sidamanik Kecamatan Pamatang Sidamanik Kabupaten Simalungun, sehingga jumlah total petani muda yang turut serta dalam FGD sebanyak 30 orang. Pemilihan peserta FGD dilakukan secara sengaja yakni petani kopi arabika dengan batasan usia petani muda kopi menurut pandangan setempat (emic), yakni berusia 20 sampai dengan 40 tahun. Subyek penelitian dalam wawancara mendalam adalah petani muda kopi yang terlibat dalam usaha kopi yang dipilih secara sengaja dengan teknik snowball (bola salju). Data jenuh pada subyek penelitian ke 11. Wawancana mendalam dengan subyek penelitian dilakukan semi terstruktur 
menggunakan pedoman wawancara.

Sebagai penelitian kualitatif, data yang dianalisis berupa kata-kata bukan rangkaian angka. Data yang telah dikumpulkan dengan cara FGD dan wawancara mendalam lalu dicatat, diketik dan disunting. Analisis data dilakukan dengan model interaktif mengikuti pendapat Miles dan Huberman (1992: 16). Dalam model ini, dilakukan reduksi data, penyajian data, dan penarikan kesimpulan, yang ketiganya merupakan suatu siklus untuk memperkuat pengambilan kesimpulan Gambar 1. Artinya sebagai metode kualitatif, data yang terkumpul dan analisis pun bersifat kualitatif. Data berupa kata-kata dimaksudkan tidak untuk menarik generalisasi, namun lebih menekankan pada makna, sehingga penelitian ini ini tergolong penelitian deskriptif.

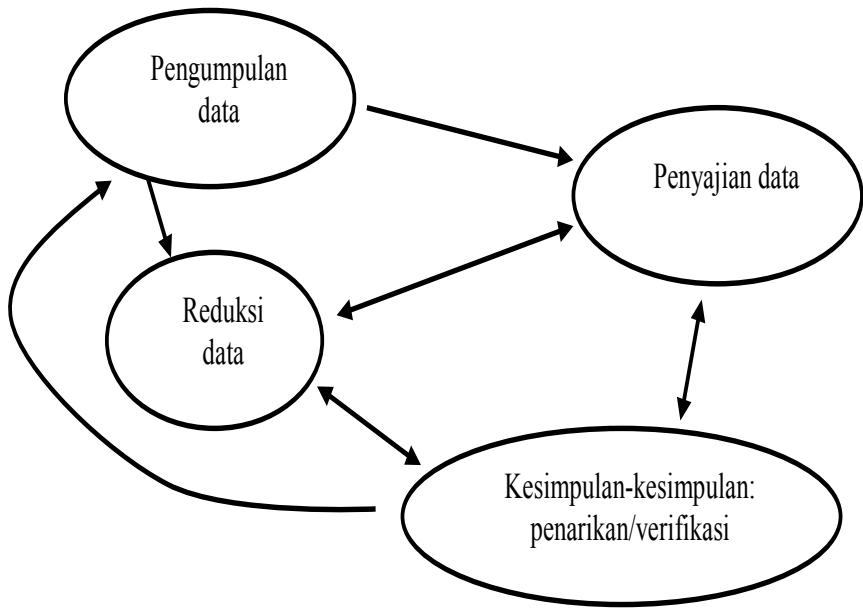

Sumber: Miles dan Huberman (1992:16)

Gambar 1. Analisis model interaktif

Langkah pertama yakni reduksi data dilakukan dengan merangkum hasil wawancara dan FGD serta fokus pada temuan penting di lapangan, lalu mencari tema dan polanya. Dengan reduksi data akan diperoleh gambaran yang lebih jelas sehingga mempermudah peneliti untuk melakukan pengumpulan data yang masih dirasa kurang. Langkah kedua yakni penyajian data dilakukan dengan penyusunan informasi untuk mempermudah dalam penarikan kesimpulan. Dalam penelitian kualitatif, data disajikan dalam berbagai bentuk, dan dalam penelitian ini data disajikan dalam bentuk teks naratif. Langkah terakhir yakni penarikan kesimpulan yang dilakukan dengan menjawab rumusan masalah yang telah ditetapkan sejak awal. Penarikan kesimpulan dalam penelitian ini dilakukan dengan mendialogkan data hasil temuan di lapangan dengan teori-teori serta hasil penelitian terdahulu.

\section{Hasil dan Pembahasan}

Pada bab pembahasan ini dibagi menjadi $3 \mathrm{sub}$ bab, yakni tipologi petani muda kopi, faktor penggerak dan pelancar dalam strategi pemberdayaan petani muda kopi serta persiapan petani muda kopi dalam kaitan dengan era pasar bebas (MEA) sesuai dengan pertanyaan dan tujuan penelitian. Penjelasan setiap sub bab adalah sebagai berikut.

\section{Tipologi Petani Muda Kopi}

Menurut White (1980; 1991), strategi penghidupan rumahtangga petani dibedakan menjadi 3 (tiga) yakni strategi survival, konsolidasi dan akumulasi. Strategi survival yakni strategi untuk memenuhi kebutuhan hidup pada tingkat minimum agar petani dapat bertahan hidup. Strategi konsolidasi adalah strategi petani untuk memenuhi kebutuhan hidup (baik kebutuhan pokok maupun kebutuhan sosial). Strategi akumulasi adalah strategi pemenuhan kebutuhan hidup baik kebutuhan pokok, sosial maupun penumpukan modal (kapital). Strategi yang dilakukan oleh satu masyarakat bisa berbeda-beda disesuaikan dengan kondisi ekonomi rumahtangga. Pada penelitian ini, strategi penghidupan rumahtangga petani dipergunakan oleh penulis untuk menentukan tipologi petani muda kopi.

Mengacu pada konsep White (1980, 1991), tipologi petani muda kopi di Kecamatan Pamatang Sidamanik dibedakan menjadi 3 (tiga), yaitu petani muda yang berusaha tani kopi dengan tujuan masih untuk bertahan hidup (survival), konsolidasi hingga untuk akumulasi kapital. Rumah tangga yang belum bisa mencukupi kebutuhan dasarnya masuk dalam kelompok strategi survival, rumah tangga mampu memenuhi kebutuhan dasar dan mampu menghadapi fluktuasi perubahan pendapatan sewaktu-waktu masuk tipologi strategi konsolidasi dan rumah tangga yang sudah berlebih sehingga mampu melakukan investasi masuk tipologi strategi akumulasi.

Pertama, Petani muda kopi yang bertipologi bertahan hidup (survival) memiliki ciri semua hasil penjualan kopi arabika dipergunakan untuk memenuhi kebutuhan hidup minimal yakni pangan untuk tujuan bertahan hidup (Saptari, 1997). Sekalipun kopi arabika diproduksi untuk tujuan ekspor, namun hasilnya hanya cukup untuk memenuhi kebutuhan dasar saja. Karakter petani muda tipologi ini umumnya masih tinggal bersama orangtua, masih mengandalkan 
sumberdaya manusia (human capital) dengan bekerja sebagai tenaga kerja upahan di kebun kopi maupun perusahaan (PT. Toba Pulp Lestari) untuk mendapatkan uang tunai pada masa kopi arabika tidak panen (track). Artinya petani muda kopi dengan strategi survival hanya mengandalkan tenaga kerja (human capital) untuk bertahan hidup, karena kepemilikan sumberdaya (aset) lain seperti lahan relatif terbatas, hanya mengelola ladang milik orang tuanya. Modal utama dalam bekerja hanyalah tenaga kerja, sehingga untuk memenuhi kebutuhan hidupnya petani muda harus senantiasa sehat, karena sakit berarti kehilangan sumber nafkah karena tidak dapat bekerja.

Untuk memenuhi kebutuhan dasarnya, petani muda kopi dengan tipologi survival melakukan dua strategi sekaligus, yakni menjadi tenaga kerja upahan untuk meningkatkan sumber dana rumahtangga serta melakukan tindakan-tindakan dengan membatasi konsumsi rumahtangga akan barang dan jasa. Upaya mengadopsi lebih dari satu strategi dilakukan petani muda kopi untuk mempertahankan hidupnya.

Kedua, Tipologi petani muda kopi untuk tujuan konsolidasi. Menurut White (1991), tipologi konsolidasi umumnya diterapkan oleh kelompok menenngah yang mengutamakan stabilitas pendapatan dari pengolahan sumberdaya yang dimiliki. Petani muda kopi di Simalungun tipologi konsolidasi umumnya mulai inisiatif memelihara kopi dengan menerapkan Good Agricultural Practice (GAP) dan SOP agar kopi yang diproduksi memenuhi standar pasar global (MEA). Usaha memelihara kopi dengan prinsip-prinsip GAP dan sesuai SOP diperoleh dari berbagai tenaga agronomis dari pendamping eksportir, seperti ECOM-Indocafco maupun dari Sumatera Specialty Cofffee (SSC) hingga starbucks selaku pembeli(buyer). Para pendamping eksportir umumnya memiliki tenaga agronomis sebanyak 3 (tiga) orang, 2 orang bagian budidaya dan seorang bagian hama dan penyakit tanaman kopi. Petani muda kopi yang menerapkan GAP dan SOP dapat bertanya langsung pada pendamping eksportir untuk mempelajari teknik budidaya kopi yang benar untuk mendapatkan hasil panen yang besar secara kuantitas dan bermutu tinggi.

Petani kopi dengan strategi konsolidasi menganggap kopi sebagai tanaman tabungan. Untuk memenuhi kebutuhan akan uang tunai, petani muda kopi menanam tanaman muda seperti: cabe rawit, cabe merah, tomat, jagung yang berumur lebih pendek sehingga cepat panen di sela-sela tanaman kopi. Petani muda kopi dengan strategi konsolidasi umumnya memiliki pekerjaan di sektor jasa (misal salon, reparasi motor maupun sopir). Hasil bekerja di sektor jasa disimpan sebagai tabungan untuk mengembangkan usaha, termasuk untuk membeli ladang kopi secara bertahap.

Uraian di atas menunjukkan bahwa petani muda kopi tipologi konsolidasi berhasil melakukan konsolidasi asset (sumberdaya) serta mampu meningkatkan produksi secara bertahap. Namun demikian tak jarang petani muda yang mengalami kegagalan dalam melakukan konsolidasi sehingga turun menjadi petani yang baru mampu memenuhi kebutuhan dasarnya (survival).

Ketiga, Tipologi petani muda kopi untuk tujuan akumulasi adalah petani muda kopi yang telah menguasai teknologi pasca panen atau teknologi di hilir. Jumlah petani dengan tipologi ini masih terbatas. Berbagai alat pengolah kopi dari alat yang menghasilkan green bean, kopi sangrai hingga kopi bubuk telah dikuasai. Berkat jaringan yang dimilikinya petani muda kopi pun dapat mengakses berbagai macam alat pengolah kopi dari berbagai instansi, mulai dari kementerian pertanian, Dirjen P2HP, Dinas Perkebunan Propinsi maupun Kabupaten Simalungun hingga bantuan Bank Indonesia. Seluruh peralatan diperoleh karena kelembagaan yang kuat, dalam bentuk kelompok tani (Taruna Tani). Beberapa alat pengolah kopi tersebut adalah: Satu unit pulper kapasitas 500 kilogram per jam dari Dirjen P2HP (tahun 2013) senilai 30 juta rupiah, satu unit huller kapasitas 400 kilogram per jam dari Dirjen P2HP (tahun 2013) senilai 40 juta rupiah, satu unit huller kapasitas 2,5 sampai 3 ton per jam dari Bank Indonesia (tahun 2015) senilai 207 juta rupiah, satu unit mesin sortir kapasitas 1 ton per jam dari Dirjen P2HP (tahun 2013) senilai 30 juta rupiah, satu unit mesin sangrai (roasting) kapasitas 20 kilogram dari dirjen P2HP (tahun 2013) senilai 73 juta rupiah, satu unit mesin press Aluvo kapasitas 100 kilogram per jam dari Dirjen P2HP (tahun 2013) senilai 13 juta rupiah, satu unit hand tractor dari menteri pertanian (tahun 2015) senilai 43 juta rupiah. Alat pengolah kopi dikelola di tingkat kelompok dengan sistem bagi hasil 20 persen untuk kas kelompok, 40 persen untuk operasional tenaga kerja (upah tenaga kerja) dan 40 persen untuk cadangan biaya perawatan peralatan.

Petani muda kopi yang sudah berstrategi akumulasi sudah berposisi dalam kelompok tani, dan orientasi usahanya sudah berubah dari petani produsen menjadi petanipemasok. Denganjaringanyangdimiliki, petani muda dapat mengakses pembibitan kopi seluas 
2 rante (800 meter persegi) dengan kapasitas 25.000 bibit kopi bantuan dari (Conservation International Indonesia) atau CII dan starbucks (tahun 2013) senilai 43 juta rupiah dan saung tani senilai 52 juta rupiah dari CII dan starbucks (tahun 2014). Saung tersebut dipergunakan untuk tempat penyuluhan dan pelatihan bagi petani kopi (farmer training coffee conservation and organic). Jaringan yang dikuasai petani muda kopi yang telah berposisi dalam kelompok tani mampu mengakses pasar bebas (MEA). Teknologi (internet) sangat membantu petani muda kopi mendapatkan informasi harga kopi langsung dari eksportir yaitu Sumatera Specialty Coffee (SSC) dan Specialty Coffee Asociatioan American (SCAA).

Penggunaan IT pemasaran kopi arabika sumatera simalungun berbasis teknologi (on line). Petani muda kopi yang berstrategi akumulasi umumnya berciri innovator, dengan ciri berani mencoba halhal yang baru, akses berbagai pelatihan seperti test cupper selama 2 minggu yang diselenggarakan oleh Sustainable Coffee Platform Indonesia (SCOPI) Jakarta dengan biaya 48 juta rupiah, sebesar 42 juta rupiah diperoleh dari Kemenkumham. Petani muda kopi menyadari bahwa dalam dunia usaha, jaringan yang luas mutlak diperlukan. Upaya memperluas jaringan pasar juga dilakukan dengan mengikuti berbagai pameran baik di dalam maupun luar negeri atas sponsor beberapa lembaga, diantaranya adalah: kementerian perdagangan, kementerian pertanian, kementerian koperasi dan UMKM hingga Kemenkumham dan kerjasama dengan Badan Ekonomi Kreatif ${ }^{1}$ (Bekraf) Jakarta.

Senada dengan temuan White (1991) dan Saptari (1997), dimana petani dengan strategi akumulasi telah mampu secara berlebih untuk memenuhi kebutuhan dasarnya sehingga mampu melakukan investasi dan mengembangkan usahanya baik di bidang pertanian maupun bidang lain. Skala usaha yang digelutinya tergolong besar, memiliki lahan dan mampu melakukan investasi. Tambahan dari studi ini adalah kemampuan petani muda dalam melakukan investasi didukung oleh jaringan (network) yang dimiliki oleh petani muda kopi untuk memperluas jaringan pasar kopi serta mengakses peralatan atau mesin pengolah kopi yang bernilai ratusan juta rupiah. Kemampuan petani muda kopi untuk melakukan investasi atau akumulasi modal ditunjukkan dengan

1. Badan Ekonomi Kreatif adalah lembaga pemerintah non kementerian yang berada di bawah dan bertanggung jawab kepada presiden melalui menteri yang membidangi urusan pemerintahan di bidang pariwisata. Bekraf dibentuk era presiden Joko Widodo. kemampuannya dalam menabung baik dalam bentuk uang maupun asset atau barang lainnya. Dengan modal yang dimilikinya, peluang untuk melakukan investasi, diversifikasi melalui pengembangan usaha (termasuk usaha pengolahan kopi arabika) sangat dimungkinkan. Ciri lain dari petani dengan tipologi akumulasi adalah berani menanggung resiko dan telah memiliki perilaku kewirausahaan (entrepreneurial behavior) sebagai respon terhadap tuntutan pasar dan perubahan lingkungan. Penelitian ini memperkuat hasil penelitian Zainura et al., (2016) dimana faktor kewirausahaan yang ditunjukkan oleh petani kopi arabika Gayo menentukan berhasil tidaknya petani kopi dalam menyesuaikan dengan perubahan lingkungan. Perilaku kewirausahaan berperan penting dalam peningkatan kinerja usahatani dan dengan ketekunan, tanggap terhadap peluang, inovatif, berani menanggung resiko serta kemandirian maka akan memberikan pengaruh pada kinerja usahatani kopi arabika Gayo (Zaunira el al., 2016).

Ketiga tipologi petani muda kopi yang telah diuraikan bersifat dinamis dan berkaitan dengan pemanfaatan sumberdaya yang dimiliki oleh rumahtangga petani muda kopi. Artinya petani muda kopi yang semula bertipologi survival dapat meningkatkan taraf penghidupannya menuju tipologi konsolidasi hingga ke tipologi akumulasi maupun tetap bertahan pada strategi konsolidasi. Menurut Baiquni (2007), perubahan menaik atau menurun sangat bergantung pada kemampuan rumahtangga dalam menyesuaikan dengan perubahan eksternal baik di tingkat makro, meso maupun mikro.

\section{Faktor Penggerak dan Pelancar dalam Strategi Pemberdayaan Petani Muda Kopi}

Menurut Ife (1995), pemberdayaan diartikan sebagai pemberian "power" atau kekuasaan atau kekuatan atau daya kepada kelompok yang lemah agar memiliki kekuatan untuk berbuat. Suharto (2010) menyatakan bahwa pemberdayaan merupakan sebuah proses dan tujuan. Sebagai proses, pemberdayaan adalah serangkaian kegiatan memperkuat kekuasaan dan keberdayaan kelompok lemah dalam masyarakat, termasuk individu-individu yang mengalami masalah kemiskinan. Sebagai tujuan, pemberdayaan merujuk pada keadaan atau hasil yang dicapai oleh sebuah perubahan sosial yaitu masyarakat yang berdaya, memiliki kekuasaan atau pengetahuan dan kemampuan dalam memahami kebutuhan hidupnya. Selanjutnya 
keberhasilan dalam pemberdayaan masyarakat dapat dilihat dari keberdayaan mereka yang menyangkut kemampuan ekonomi, kemampuan mengakses manfaat kesejahteraan, dan kemampuan kultural dan politis. Ketiga aspek tersebut dikaitkan dengan empat dimensi kekuasaan, yaitu: 'kekuasaan di dalam' (power within), 'kekuasaan untuk' (power to), 'kekuasaan atas' (power over), dan 'kekuasaan dengan' (power with).

Kekuasaan di dalam (power within) dimaksudkan untuk meningkatkan kesadaran dan keinginan untuk berubah. Kekuasaan untuk (power to) dimaksudkan untuk meningkatkan kemampuan individu untuk berubah dan meningkatkan kesempatan untuk memperoleh akses. Kekuasaan atas (power over) dimaksudkan untuk perubahan pada hambatanhambatan sumber dan kekuasaan pada tingkat rumah tangga, masyarakat, dan makro, kekuasaan atau tindakan individu untuk menghadapi hambatanhambatan tersebut serta meningkatkan kesempatan untuk memperoleh akses. Sedangkan kekuasaan dengan (power with) dimaksudkan untuk meningkatkan solidaritas atau tindakan bersama dengan orang lain untuk menghadapi hambatan-hambatan sumber dan kekuasaan pada tingkat rumah tangga, masyarakat dan makro.

Merujuk pada hal tersebut, berdasarkan hasil sintesa tipologi petani muda kopi yang diperoleh melalui wawancara mendalam dan FGD, petani muda kopi wirausaha yang dianggap berdaya adalah petani muda yang memiliki karakter wirausaha, akses dan kontrol pada usaha kopi kuat, dan posisi sosial yang diakui masyarakat.

Nasdian (2013) mengungkapkan bahwa upaya pemberdayaan merupakan suatu upaya menumbuhkan peranserta dan kemandirian sehingga masyarakat baik di tingkat individu, kelompok, kelembagaan, maupun komunitas memiliki tingkat kesejahteraan yang jauh lebih baik dari sebelumnya, memiliki akses pada sumberdaya, memiliki kesadaran kritis, mampu melakukan pengorganisasian dan kontrol sosial dari segala aktivitas pembangunan yang dilakukan di lingkungannya.

Pemberdayaan dalam konteks ilmu sosial selalu menunjukkan keberpihakan pada kaum lemah dan korban-korbanpembangunanyangtidak berdaya. Nilainilai yang terkandung dalam konsep pemberdayaan adalah kesadaran(consciousness), proses, kemandirian, tanggung jawab dan juga keberlanjutan karena secara epistemologis pemberdayaan (empowerment) berakar dari teori sosial kritis (critical theory) atau paradigma kritis (Setiawan, 2012) sebagai kritik atas pandangan yang positivistik.

Sejalan dengan hal tersebut maka strategi pemberdayaan petani muda kopi wirausaha dilakukan melalui kegiatan pengembangan karakter wirausaha, pemberdayaan ekonomi, dan penyadaran pengakuan petani muda kopi. Dalam program pengembangan karakter wirausaha, dilakukan bebrapa kegiatan: (1) Pembentukan reference group (petani muda berhasil), (2) Pelatihan kewirausahaan; dan (3) Magang. Dalam program pemberdayaan ekonomi kopi, dilakukan kegiatan: (1) Peningkatan akses terhadap usaha kopi; (2) Sewa lahan jangka panjang; (3) Peningkatan akses modal sesuai musim dan kebutuhan anak muda; (4) Pelatihan teknologi (IT); (5) Demplot tumpangsari dan pengolahan hasil kopi, (6) Pilot project pedagang kopi dan pengusaha kopi. Demikian Program pengembangan sosial petani muda kopi, dilakukan kegiatan: (1) Pendampingan keluarga petani muda kopi melalui penanaman nilai positif kopi; (2) Pembentukan kelompok petani muda kopi wirausaha; (3) Pelibatan kaum muda dalam jaringan pasar; (4) Koordinasi kelompok dalam pengembangan kopi.

Upaya memberdayaan masyarakat dapat dilihat dari tiga sisi. Pertama, menciptakan suasana atau iklim yang memungkinkan potensi masyarakat berkembang (enabling). Kedua, memperkuat potensi atau daya yang dimiliki masyarakat (empowering). Ketiga, memberdayakan mengandung pula arti melindungi (Mardikanto dan Poerwoko, 2012).

Dengan demikian, dalam upaya pemberdayaan petani muda kopi wirausaha, diperlukan faktor penggerak dan pelancar. Apabila dalam pembangunan pertanian memerlukan faktor utama dan faktor pelancar (AT. Mosher, 1983), maka dari hasil FGD untuk memberdayakan petani muda kopi diperlukan faktor penggerak dan pelancar. Faktor penggerak mencakup: (1) Perubahan orientasi usaha dari non pasar menjadi pasar; (2) Asuransi/jaminan pribadi, patron klien menjadi pasar (cadangan uang tunai untuk tabungan); (3) Membuka akses pada alat produksi; (4) Membentuk citra petani muda sebagai agen yang aktif dan kritis; dan (5) Menempatkan petani muda kopi sebagai subyek yang dinamis dalam membangun karakter kepemimpinan dan kewirausahaan.

Perubahan orientasi usaha darinon pasarmenjadi pasar harus dilakukan karena kopi arabika dan hasil olahannya merupakan komoditi ekspor sehingga petani harus beradaptasi dengan tuntutan pasar. Hubunganhubungan sosial yang semula berikatan ganda dan 
berciri patron-klien sedikit demi sedikit semakin terkikis digantikan dengan hubungan yang kontraktual. Sebagai jaminan atau asuransi, petani kopi memerlukan tabungan. Upaya untuk membuka akses pada alat produksi dilakukan dengan memperkuat modal sosial baik secara vertikal (pemerintah kabupaten maupun propinsi) maupun horizontal. Upaya membentuk citra petani muda sebagai agen yang aktif dan kritis dilakukan melalui berbagai training atau pelatihan untuk meningkatkan ketrampilan dan kritis terhadap berbagai perubahan dan tuntutan pasar. Upaya membangun karakter kepemimpinan dan kewirausahaan dilakukan dengan memberikan kepercayaan pada petani muda dalam wadah kelompok tani muda (Taruna Tani) serta memberikan peluang memulai usaha dengan dukungan penuh baik dari orang tua maupun pemerintah.

Faktor pelancar mencakup: (1) Membangun kolektifitas melalui penguatan kelembagaan petani muda kopi (kelompok tani, Koperasi, Gapoktan); (2) Memperkuat modal sosial: trust/kepercayaan, jaringan, kelembangaan yang kuat; (3) Melindungi basis sumberdaya: sumber mata air, sungai, lahan subur untuk kelestarian lingkungan (good agricultural practices); (4) Diversifikasi mata pencaharian (nafkah ganda) dengan melepaskan ketergantungan pada peminjam uang; (5) Membuka akses pasar; dan (6) Memberikan penyuluhan dan pendampingan usaha kopi berbasis Inovasi Teknologi (IT). Penerapan Inovasi Teknologi ini penting untuk dilakukan karena hasil penelitian Fatchiya et al. (2016) juga menunjukkan bahwa penerapan teknologi inovasi berperan besar dalam meningkatkan produktivitas usaha tani, sehingga berpeluang untuk meningkatkan kesejahteraan hidup rumahtangga petani dengan salah satu indikator yakni ketahanan pangan rumahtangga petani.

Upaya percepatan adopsi inovasi teknologi dilakukan melalui berbagai cara. Hasil penelitian Muchtar et al. (2015) percepatan adopsi inovasi di tingkat petani untuk peningatan produksi secara berkelanjutan dilakukan melalui program Sekolah Lapangan Pengelolaan Tanaman Terpadu (SL-PTT). Namun dalam konteks petani kopi arabika di Simalungun, percepatan adopsi teknologi dilakukan dengan cara memberikan bantuan mesin pengolah kopi arabika diiringi dengan pelatihan singkat penggunaan peralatan tersebut.

\section{Persiapan Petani Muda Kopi dalam Kaitan dengan Era Pasar Bebas (MEA)}

Era Masyarakat Ekonomi Asia (MEA) menuntut kesiapan petani untuk memasuki sistem pasar bebas negara-negara yang tergabung dalam ASEAN. Pada uraian sebelumnya telah dibahas di era MEA diperlukannya penguatan kelembagaan petani, baik melalui kelompok tani, koperasi maupun Gapoktan agar dapat bernegosiasi dengan pihak luar dan membangun jaringan kerja. Jaringan merupakan salah satu unsur modal sosial. Modal sosial berkontribusi terhadap tindakan atau aksi kolektif (Meinzen-Dick et al., 2004). Aksi kolektif dalam bentuk kelembagaan dapat mencapai tujuan bersama. Hasil studi Rokhani et al., (2016) menunjukkan bahwa dengan tindakan kolektif, petani dapat mengakses pasar global, artinya pasar dengan segala tuntutannya tidak dihindari oleh petani, namun petani berusaha memenuhi segala tuntutan pasar global.

Petani muda di Kecamatan Pamatang Sidamanik Kabupaten Simalungun dapat mengakses teknologi (berupa peralatan pengolah kopi) secara berkelompok. Artinya upaya pemberdayaan petani muda selama ini menggunakan kelembagaan kelompok tani. Introduksi teknologi melalui kelompok memudahkan pemberi bantuan untuk memonitoring program. Hasil studi ini diperkuat dengan hasil penelitian Karsidi (2007) menunjukkan bahwa dengan pendekatan kelompok memudahkan pengelolaan kredit dan dapat menekan risiko sehingga secara keseluruhan layanan kredit menjadi lebih ekonomis. Pendekatan kelompok juga mempermudah pendampingan usaha bagi pengintervensi program.

Upaya untuk memberdayakan petani muda kopi tidak hanya cukup dengan introduksi teknologi pengolah kopi saja. Yang tidak kalah penting adalah mengubah paradigma petani. Menurut Sadono (2008) untuk memberdayakan petani diperlukan perubahan paradigma dari paradigma lama yang lebih menekankan pada alih teknologi ke paradigma baru yang mengutamakan pada sumberdaya manusia atau pendekatan farmer first, yakni dengan "mengubah petani", bukan "mengubah cara bertani".

Di Era MEA, peran kelembagaan petani sangat penting karena melalui kelembagaan petani dapat meningkatkan posisi tawar (bargaining position), bernegosiasi, memperluas jaringan pasar dengan membuat nota kesepahaman (MoU) dalam pemasaran hasil dengan harga yang telah disepakati. Penguatan kelembagaan memerlukan peran penyuluh sebagaimana amanah UU Nomor 16 tahun 2006 tentang Sistem Penyuluhan Pertanian Perikanan dan Kehutanan (SP3K) yang menyebut 
penyuluhan sebagai proses pembelajaran bagi pelaku utama serta pelaku usaha agar mereka mau dan mampu menolong dan mengorganisasikan dirinya dalam mengakses informasi, pasar, teknologi, permodalan dan sumberdaya lainnya, sebagai upaya untuk meningkatkan produktivitas, efisiensi usaha, pendapatan dan kesejahteraannya serta meningkatkan kesadaran dalam pelestarian fungsi lingkungan hidup.

Hasil penelitian Rahmawati dan Muksin (2016) menunjukkan bahwa peran, kinerja dan inovasi yang dilakukan oleh penyuluh berpengaruh secara langsung dan signfikan terhadap keberdayaan peternak di Kabupaten Jember. Peran dan inovasi penyuluh juga berpengaruh terhadap kinerja penyuluh di lapangan. Sebagai garda terdepan, kapasitas penyuluh harus terus ditingkatkan baik melalui pelatihan maupun pemberian motivasi atau dorongan bagi penyuluh sebab hasil penelitian Putri et al., (2016) menunjukkan bahwa frekuensi pelatihan dan motivasi dari penyuluh pertanian berpengaruh positif terhadap kinerja penyuluh. Penyuluhan pertanian oleh penyuluh adalah suatu bentuk pengaruh sosial yang disadari, artinya komunikasi dilakukan secara sengaja oleh penyuluh untuk memberikan informasi guna membantu petani membuat keputusan yang benar dan mengubah perilaku petani menjadi lebih baik (Van Den Ban dan Hawkins, 1999).

Lebih lanjut Van Den Ban dan Hawkins (1999) juga menjelaskan pentingnya teknologi yang perlu diadopsi oleh petani untuk meningkatkan produksi guna mendukung pembangunan pertanian Indonesia. Dengan teknologi diharapkan mampu meningkatkan produktivitas, mutu dan diversifikasi produk olahan di sektor hilir baik dalam skala kecil, menengah maupun besar. Dalam konteks petani muda kopi, teknologi yang diakses petani muda kopi tergolong skala menengah.

Memperkuat peran kelembagaan petani di era MEA perlu dibarengi dengan usaha mereposisi petani bukan hanya sebagai petani produsen namun juga petani pemasok. Reposisi petani merupakan implementasi dari UU Nomor 19 Tahun 2013 tentang Perlindungan dan Pemberdayaan Petani dengan memberi ruang untuk mereposisi petani dari petani produsen menjadi petani pemasok. Berbeda dengan petani produsen yang pernah diraih Indonesia pada masa revolusi hijau, dimana petani mampu memproduksi hasil pertanian melalui teknologi usaha tani.

Namun di era pasar bebas (MEA), bukan sekedar petani produsen yang dibutuhkan namun petani yang mampu merespon dan memenuhi permintaan pasar atau petani pemasok. Upaya untuk mempersiapkan petani kopi arabika yang bukan sekedar sebagai produsen namun juga sebagai pemasok juga dilakukan oleh petani kopi di Simalungun Sumatera Utara dengan dukungan berbagai pihak, baik pemerintah maupun swasta.

Dukungan swasta di Simalungun ditunjukkan dengan keberdaan ECOM-Indocafco, perusahaan eksportir terbesar kedua dari pelabuhan Belawan yang turut serta mendampingi petani muda kopi mulai dari budidaya hingga pasca panen. Upaya mendampingi petani muda kopi, eksportir menerjunkan para agronomis untuk mendampingi usaha petani muda kopi agar melakukan proses produksi sesuai dengan SOP dan menerapkan Good Agricultural Practice (GAP). Dukungan pemerintah kepada petani muda kopi dilakukan dengan memberikan bibit kopi arabika hingga bantuan mesin pengolah kopi dengan hasil akhir baik kopi gabah, green bean maupun kopi bubuk.

\section{Kesimpulan}

Terdapat tiga tipologi petani muda kopi, yaitu survival, konsolidasi dan akumulasi dalam strategi bernafkah ganda. Tipologi petani muda kopi yang berstrategi akumulasi memiliki skala usaha besar, menguasai teknologi pengolahan kopi, telah berposisi dalam kelompok tani dan berposisi sebagai petani produsen sekaligus pemasok. Petani muda kopi dengan strategi survival maupun konsolidasi masih fokus pada usaha lain (bukan usaha kopi), skala usahanya relatif kecil, belum berposisi di dalam kelompok tani, baru sebagai petani produsen belum menjadi petani pemasok. Strategi pemberdayaan petani muda kopi wirausaha memerlukan dua komponen, yaitu: faktor penggerak dan pelancar.

Faktor penggerak meliputi: perubahan sistem ekonomi non pasar menjadi pasar, perubahan sistem patron klien menjadi pasar; membuka akses alat pengolahan kopi, membentuk citra petani muda sebagai agen yang aktif dan kritis, menempatkan petani muda kopi sebagai subyek yang dinamis dalam membangun karakter kepemimpinan dan juga kewirausahaan. Faktor pelancar meliputi: membangun kolektivitas, mengorganisir petani muda kopi dengan memperkuat modal sosial, melindungi basis sumberdaya air dan lahan dengan menerapkan good agricultural practices $(G A P)$, diversifikasi mata pencaharian, membuka akses pasar, penyuluhan dan pendampingan usaha kopi berbasis informasi dan teknologi. 


\section{Daftar Pustaka}

Antara. (2012,April 19). AS, Perancis, Jepang, Hongkong Tertarik Kopi Arabika Simalungun. [internet]. [dapat diunduh di http://www.medanmagazine.com/]

Baiquni M. 2007. Strategi Penghidupan di Masa Kritis. Yogyakarta (ID): Idial Media.

Fatchiya A, Amanah S, Kusumastuti YI. 2016. Penerapan Inovasi Teknologi Pertanian dan Hubungannya dengan Ketahanan Pangan Rumah Tangga Petani. Jurnal Penyuluhan, 12(2): 190-197.

Ife J. 1995. Community Development, Creating Community Alternatives: Vision, Analysis and Practice. Australia: Longman.

Karsidi, R. 2007. Pemberdayaan Masyarakat Untuk Usaha Kecil dan Mikro (Pengalaman Empiris di Wilayah Surakarta Jawa Tengah). Jurnal Penyuluhan, 3(2).

Mardikanto T, Poerwoko S. 2012. Pemberdayaan Masyarakat Dalam Perspektif Kebijakan Publik. Bandung (ID): Alfabeta.

Meinzen-Dick R, Di Gregorio M. 2004. Collective Action and Property Rights for Sustainable Development. 2020VisionforFood,Agriculture and theEnvironment. Focus 11, Brief 1. Washington DC (US): IFPRI.

Miles M, AM Huberman. 1992. Analisis Data Kualitatif: Buku Sumber Tantang Metode-Metode Baru. Jakarta (ID): UI Press.

Moeleong L. 2007. Metodologi Penelitian Kualitatif. Bandung (ID): PT.Remaja Rosdakarya.

Mosher AT. 1983. Menggerakkan dan Membangun Pertanian. Jakarta (ID): Yasaguna.

Muchtar K, Susanto J, Purnaningsih N. 2015. Adopsi Teknologi Petani pada Sekolah Lapangan Pengelolaan Tanaman Terpadu (SL-PTT). Jurnal Penyuluhan, 11(2): 176-185.

Nasdian, FT. 2013. Pengembangan Masyarakat. Bogor (ID): IPB Press.

Ningsih F, SjafS. 2015. Faktor-Faktor yang Menentukan Keterlibatan Pemuda Pedesaan pada Kegiatan Pertanian Berkelanjutan. Jurnal Penyuluhan, 11(1): 23-37.

[PDSIP] Pusat Data dan Sistem Informasi Pertanian. 2013. Analisis dan Proyeksi tenaga Kerja Pertanian 2013-2019. Jakarta (ID).

Putri IW, Fatchiya A, Amanah S. 2016. Pengaruh Pelatihan Non Teknis terhadap Kinerja Penyuluh Pertanian BP4K di Kabupaten Bungo Propinsi Jambi. Jurnal Penyuluhan, 12(1).

Rahmawati IR, Muksin R. 2016. Peran dan Kinerja Penyuluh Pertanian dalam Memberdayakan Peternak
Ayam Petelur di Kabupaten Jember, Provinsi Jawa Timur. Jurnal Penyuluhan, 12(2):183-189.

Rokhani, Sumarti T, Damanhuri DS, Wahyuni ES. 2016. Dilema Kolektivitas Petani Kopi: Tinjauan Sosiologi Weberian (Kasus Petani Kopi di Nagori Sait Buttu Saribu, Kecamatan Pamatang Sidamanik Kabupaten Simalungun, Sumatera Utara). Sodality Jurnal Sosiologi Pedesaan, 4(1).

Sadono D. 2008. Pemberdayaan Petani: Paradigma Baru Penyuluhan Pertanian di Indonesia. Jurnal Penyuluhan, 4(1).

Saptari R. 1997. Social Security and The Study of Java: Concepts, Issues and Problems. Workshop Social Security. Yogyakarta (ID): Pusat Penelitian Kependudukan UGM.

Setiawan I. 2012. Dinamika Pemberdayaan Petani. Sebuah Refleksi dan Generalisasi Kasus di Jawa Barat. Bandung (ID): Widya Padjajaran.

SuhartoE.2005.MembangunMasyarakatMemberdayakan Rakyat: Kajian Strategis Pembangunan Kesejahteraan Sosial \& Pekerja Sosial. Bandung: PT Refika Aditama. [UU] Undang-Undang Republik Indonesia Nomor 16 Tahun 2006 tentang Sistem Penyuluhan Pertanian, Perikanan dan Kehutanan.

[UU] Undang-Undang Republik Indonesia Nomor 19 Tahun 2013 tentang Perlindungan dan Pemberdayaan Petani.

White BNF. 1980. Rural Household Studies in Anthropological Perspective. Bunga rampai: Rural Household Studies in Asia. Singapore: Singapore University Press. and Agrarian Change in Rural Java 1900-1990. Pp 41-49. Alexander, Paul, Boomgard, Peter and White, Benjamin (eds). 1991. In the Shadow of Agrarculture: Non Farm Activities in Javanese Economy, Past and Present. Amsterdam: Royal Tropical Institute

Van Den Ban AW, HS Hawkins. 1999. Penyuluhan Pertanian. Yogyakarta (ID): Kanisius.

Zainura U, Kusnadi N, Burhanuddin. 2016. Perilaku KewirausahaanPetaniKopiArabika GayodiKabupaten Bener Meriah Provinsi Aceh. Jurnal Penyuluhan, 12(2): 126-143. 